\title{
Macroalgal traits and the feeding and fitness of an herbivorous amphipod: the roles of selectivity, mixing, and compensation
}

\author{
Edwin Cruz-Rivera ${ }^{1}$, Mark E. Hay ${ }^{2, *}$ \\ ${ }^{1}$ University of Guam Marine Laboratory, UOG Station, Mangilao, Guam 96923, USA \\ ${ }^{2}$ School of Biology, Georgia Institute of Technology, Atlanta, Georgia 30332-0230, USA
}

\begin{abstract}
Selective feeding, compensatory feeding, and diet mixing have all been proposed as adaptive strategies allowing herbivores to enhance nutrient intake from low quality plant and algal foods. However, little is known about the relative importance of these alternative feeding strategies for consumer fitness or about how these strategies are affected by prey nutritional traits. To address this, we studied the effects of algal nutritional value and toughness on feeding choices, feeding rates, and survival, growth and fecundity of the amphipod Ampithoe longimana. To assess the value of diet mixing, we compared fitness of amphipods cultured on each of 15 algal species or on 4 different mixtures of algae. We also quantified how sequentially switching between algae that supported higher and lower fitness affected fitness compared to monospecific diets of these algae and to a constant mixture of the algae. Protein, nitrogen, organic content, or toughness of algae did not correlate with food choice by $A$. longimana. In contrast, we found a strong inverse correlation between feeding rates and algal organic content [ash free dry mass/wet mass (AFDM:WM) and total organic carbon (TOC)], and, to a lesser extent, protein (but not nitrogen). Thus, when confined with algae having lower nutritional value, $A$. longimana used quantity to compensate for quality. This compensatory feeding was confirmed by feeding amphipods on artificial diets that varied only in their amount of AFDM:WM. Despite broad differences in algal nutrient content or other traits, compensatory feeding allowed this amphipod to maintain high fitness when cultured on most, but not all, algae. Access to algal mixtures did not enhance fitness compared to feeding on several algae offered alone, suggesting that $A$. longimana need not rely on a mixed diet. Even when significant differences in survivorship or growth occurred between a monospecific diet and a mixed diet, fecundity or size of eggs produced by egg-bearing survivors were generally unaffected. Furthermore, when amphipods were switched sequentially (every 24 h) between 2 different quality algae, only growth (but not survivorship, fecundity, or egg size) was affected, with growth determined primarily by the higher quality alga offered. Amphipods confined with the green alga Codium fragile ovulated significantly later than conspecifics on one mixed diet, but this effect was observed only in 1 of 2 long-term assays. Thus, dietary mixing offered only a moderate benefit to this amphipod under very restrictive conditions. For A. longimana, food selection is relatively unresponsive to algal nutritional quality, apparently because compensatory feeding allows this amphipod to successfully exploit a variety of algal foods. Compensatory feeding also may reduce the need to move among host algae in order to mix diets, thus decreasing the risk of movement-associated detection by predators.
\end{abstract}

KEY WORDS: Ampithoe longimana - Compensatory feeding · Diet mixing · Dietary effects on fitness · Herbivore food choice $\cdot$ Mesograzers $\cdot$ Alga nutritional quality

Resale or republication not permitted without written consent of the publisher

\section{INTRODUCTION}

Marine algae vary considerably in their nutritional, chemical, and structural composition, thus providing a

${ }^{*}$ Corresponding author. E-mail: mark.hay@biology.gatech.edu heterogeneous and variable food resource for marine herbivores (Hay \& Fenical 1988, Neighbors \& Horn 1991, Paul 1992, Bolser \& Hay 1996, Kaehler \& Kennish 1996, Kennish \& Williams 1997, Wakefield \& Murray 1998, Poore \& Steinberg 1999). Because herbivores eat foods that are much lower in nutrients than their own 
tissues (Southwood 1973, Mattson 1980, White 1993, Sterner \& Hessen 1994, Gulati \& DeMott 1997), they display a diversity of behavioral and physiological adaptations to cope with the low nutritional value of their foods (Mattson 1980, White 1993). Nutrition is a complex process, dependent not only on availability of nutrients, but also on nutrient balance. Thus, selective feeding on more nutritious plants, mixing foods to balance nutritional needs, switching plant hosts, and increasing consumption of lower quality foods (compensatory feeding) have all been proposed as important behaviors allowing herbivores to obtain adequate nourishment from low quality, or nutritionally unbalanced, plant food (Mattson 1980, Simpson \& Simpson 1990, Pennings et al. 1993, White 1993, Stoyenoff et al. 1994, Stachowicz \& Hay 1999, Cruz-Rivera \& Hay 2000a,b, but see Bernays \& Minkenberg 1997).

Although these diverse feeding strategies have been studied for a wide variety of organisms, investigations usually focus on these behaviors independently, rather than assessing the relative importance of different feeding strategies for the same organism. Animals are often variable in their behaviors and may feed using different modes depending on environmental constraints. For example, predators may feed indiscriminately when prey are scarce, but may become more selective when particular prey are more abundant (Werner \& Hall 1974, Stephens \& Krebs 1986, Begon et al. 1996). Similarly, herbivores may switch host plants during their development (Stoyenoff et al. 1994), or may vary in their relative preference for different foods depending on geographic or temporal availability, and on herbivore feeding history (Fox \& Morrow 1981, Strong et al. 1984, Pennings et al. 1993, Cronin \& Hay 1996a, Bernays \& Minkenberg 1997). Thus, an organism may feed selectively or be better able to mix specific diets when preferred foods are abundant, but become less discriminate or rely on compensatory feeding when preferred foods are scarce or when access to them is limited by biotic or abiotic factors (Stephens \& Krebs 1986, Pennings et al 1993, Begon et al. 1996, Cruz-Rivera \& Hay 2000a,b). The use of multiple feeding strategies may be of particular importance for certain marine herbivores that live year-round in environments in which algal communities change considerably with season (e.g., Duffy \& Hay 1994, Kennish 1997).

Diverse feeding strategies are often treated as adaptive (White 1993). This assumes that a positive correlation exists between the feeding behavior observed and the fitness consequences of the behavior (Pyke 1984, Stephen \& Krebs 1986). Although reasonable, this assumption is rarely tested (see discussions in Pennings et al. 1993, Lindquist \&
Hay 1995). Studies measuring both consumer feeding and fitness are particularly rare in marine systems, where the practicality of long-term experiments is limited because of the long and complex life cycles of many marine animals, the lack of knowledge of natural diets, and the difficulty of maintaining consumers for long periods.

Marine organisms with simpler life histories (such as amphipods) can provide useful tools for measuring how different feeding strategies relate to fitness. Most amphipods are small direct developers, with relatively short generations (Bousfield 1973, Barnard \& Karaman 1991). A number of species have been cultured on diverse diets and have provided useful information on how particular foods relate to fitness variables in these organisms (Robertson \& Lucas 1983, Duffy \& Hay 1991a, DeLong et al. 1993, Graça et al. 1993, Knieb et al. 1997, Poore \& Steinberg 1999, Cruz-Rivera \& Hay 2000a,b).

We studied the relation between feeding behavior and fitness of the herbivorous amphipod Ampithoe longimana, and how this relationship was affected by nutritional and structural traits of temperate algae. We selected this organism because it is widely distributed along the Atlantic coast of North America (Bousfield 1973) and because studies suggest $A$. longimana uses diverse feeding strategies in the field. For example, $A$. longimana prefers to live on, and feed from, the brown macroalga Dictyota menstrualis, but will associate with, and feed on, other macroalgae, epiphytes and seagrasses (Nelson 1979, Hay et al. 1987, Bell 1991, Duffy \& Hay 1991a,b, 1994, 2000, Cronin \& Hay 1996b). This amphipod can have strong effects on its preferred host D. menstrualis (Cronin \& Hay 1996b), as well as on macroalgal community structure in general (Duffy \& Hay 2000). At our field sites, Dictyota only occurs during the warmer months whereas $A$. longimana is found throughout the year (Duffy \& Hay 1991a, 1994), so access to the preferred algal host is seasonally limited. Gut contents suggest $A$. longimana mixes diverse foods as part of its diet (Nelson 1979), but the amphipod also demonstrates compensatory feeding (Cruz-Rivera \& Hay 2000a). Thus, A. longimana may be capable of using different feeding modes depending on location, food availability, and other environmental constraints. We evaluated the relative importance of these feeding modes by addressing: (1) how algal nutrients and toughness influenced the feeding choices, consumption rates, and long-term fitness of this amphipod; (2) whether simultaneous access to algal mixtures enhanced fitness over feeding on single species; and (3) how sequentially switching between low and high quality algae (a type of dietary mixing) affected amphipod fitness. 


\section{MATERIALS AND METHODS}

Analysis of algal traits. Both nutritional and structural traits can affect algal suitability to herbivores. To assess the relative nutritional quality of algae, we measured wet to dry mass ratios, protein, nitrogen, total organic carbon (TOC), ash content, and toughness of diverse seaweeds ( $\mathrm{n}=9$ to 10 for each species) common to North Carolina, USA. We also calculated ashfree dry mass (AFDM), and the carbon to nitrogen ratio of the algae. Nutrient measurements in published works generally are presented as proportions of dry mass; however, algal water content can dilute nutrients, having consequences for nutrient acquisition by herbivores. Thus, we present data on algal nutritional quality as proportions of both dry mass (which allows comparisons with other published works), and wet mass (which is how herbivores may perceive the alga). Not all of these parameters could be measured for all algal species because of methodological limitations or scarcity of some samples (explained below).

Most algae were collected from field sites near Morehead City, North Carolina, USA $\left(34^{\circ} 42^{\prime} \mathrm{N}\right.$, $76^{\circ} 41^{\prime} \mathrm{W}$ ), but some of the most palatable species, which were rare in the field, were obtained from large outdoor mesocosms at the University of North Carolina's Institute of Marine Sciences in Morehead City. The mesocosms receive raw seawater from Bogue Sound, which is where our field collections were made. The mesocosms do not contain herbivorous fishes or urchins, but algae recruit readily. Algae were selected to include green, red, and brown macroalgae, and represented a range of morphologies, life histories, and habits (see Schneider \& Searles 1991). Species used included the green algae Enteromorpha intestinalis, Chaetomorpha linum, Codium fragile, and Ulva curvata; the red algae Chondria dasyphylla, Gracilaria tikvahiae, Hypnea musciformis, and Spyridia filamentosa; and the brown algae Dictyota menstrualis, Ectocarpus siliculosus, Fucus vesiculosus, Padina gymnospora, and Sargassum filipendula.

Our data relate algal traits to both short-term (feeding responses) and long-term (fitness) effects on an amphipod consumer. Because algal nutrient composition can vary through time (Duffy \& Hay 1991a, Kahler \& Kennish 1996), we collected samples for determining tissue traits at 9 to 10 different times scattered haphazardly throughout the $55 \mathrm{~d}$ (from 1 October to 24 November) that our experiments ran. On each of these sampling dates, we collected one individual of each test species for analysis and processed these as outlined below. The low within-species variance we found for these traits (see results section) indicates that traits of our test species changed very little over the time course of our assays.
To determine wet to dry mass ratios and percentage of ash, algal pieces were blotted to remove excess water and weighed. They were then dried at $60^{\circ} \mathrm{C}$ for a maximum of $3 \mathrm{~d}$, reweighed, and burned in a furnace at $500^{\circ} \mathrm{C}$ for at least $8 \mathrm{~h}$. Protein, nitrogen, and TOC were measured on algal samples that were freezedried, ground, and stored at $-20^{\circ} \mathrm{C}$ until measurements were made. Percentage of protein from these samples was determined colorimetrically by Bradford's method (Bradford 1976), using bovine albumin serum as the standard, and quantifying sample absorbance at 595 $\mathrm{nm}$ (see general methods for this assay in Duffy \& Hay 1991a). Although Bradford's method provides only a relative measurement of total soluble protein, it is widely used and considered reliable for comparisons of relative protein content (Davis 1988, but see Crossman et al. 2000). Nitrogen and TOC were measured by combustion in a Carlo Erba NA1500 CHN analyzer. When making these nutritional measurements, Spyridia and Ectocarpus were unavailable in the field. Thus, for Spyridia we could not determine wet to dry mass ratio, but ash content was determined from freeze-dried samples stored previously. For Ectocarpus, we had only enough material to determine nitrogen and total organic carbon.

Algal toughness was determined using a penetrometer (Duffy \& Hay 1991a) that quantified the force needed to pierce through an algal thallus. With this method, we could measure toughness only for algae with broader thalli and solid epidermal layers for which the penetrometer readings were reliable. Because filaments of Ectocarpus siliculosus were too narrow, and Codium fragile lacked a cohesive outer layer (i.e., it is formed by densely packed filaments, Schneider \& Searles 1991), toughness of these algae could not be reliably measured.

Feeding assays. Ampithoe longimana were obtained from field collections of algae and from cultures maintained in outdoors flow-through tanks at the Institute of Marine Sciences. The tanks contained algal mixtures, mainly of Sargassum filipendula, Dictyota menstrualis, Enteromorpha spp. and Ulva spp. Undefaunated algae were brought from the field and placed in the tanks approximately every 2 wk. Therefore, amphipods from field populations were added regularly to the cultures. A. longimana attained high numbers in these cultures, providing a reliable supply of test animals at times of the year when amphipod were scarce in the field due to predation.

The food choices of Ampithoe longimana were studied by simultaneously offering the amphipod 8 species of common macroalgae that co-occurred on subtidal hard substrates along the coast of North Carolina (Codium fragile, Ulva curvata, Chondria dasyphilla, Gracilaria tikvahiae, Hypnea musciformis, 
Dictyota menstrualis, Padina gymnospora, and Sargassum filipendula). All these algae were collected from Radio Island Jetty, which is the nearby site with the most diverse algal community. Thus, amphipods were offered a multiple choice among seaweeds that grow sympatrically and often in contact with each other. We did not include other algae that were scarce or did not occur on Radio Island Jetty. Pieces of each alga (100 to $200 \mathrm{mg}$ ) were placed in each of 30 replicate containers. Eight adult A. longimana were added to 20 of the containers and allowed to feed for a maximum of $2.5 \mathrm{~d}$. The remaining containers served as controls for autogenic changes in algal mass (Peterson \& Renaud 1989). Upon termination of this multiple-choice assay, amphipods were removed, changes in algal mass were measured, and consumption was calculated after correcting for mass changes unrelated to amphipod feeding (Peterson \& Renaud 1989, Cronin \& Hay 1996b).

Because herbivores may increase their feeding rates to compensate for low food quality (compensatory feeding), we also measured feeding by Ampithoe longimana when different algae were offered alone (no-choice assays). Twelve algal species were tested by placing 3 adult $A$. longimana in each of 180 replicate containers $(n=15$ per algal species). Pieces of only 1 algal species (100 to $200 \mathrm{mg}$ ) were randomly assigned to each container, and the amphipods were allowed to feed for $2 \mathrm{~d}$. For each alga, 6 additional containers received algae but no amphipods and served as controls for autogenic changes in mass. Algal pieces were weighed again at the end of the experiment and the changes in mass calculated. This no-choice experiment assessed the feeding rates of A. longimana on Chaetomorpha linum, Enteromorpha intestinalis, Fucus vesiculosus, and Spyridia filamentosa, in addition to the 8 species of algae that were offered simultaneously during the multiple-choice assay (above).

Because compensatory feeding can occur in response to variation in nutrients or other algal traits, we used regressions to determine if Ampithoe longimana was feeding in a compensatory manner, and what algal traits could best explain that behavior. Additionally, we tested if $A$. longimana compensated for lower food quality by measuring the feeding rates of the amphipod when confined with artificial diets that varied only in their amount of organic content per wet mass. The artificial foods were made using the basic methods described in Hay et al. (1994, 1998b). Diets were prepared by using freeze-dried, ground Enteromorpha spp. suspended in a matrix of agar that was fixed onto strips of plastic screen mesh. As amphipods fed, the squares of the plastic screen were cleared of food, and consumption per unit of time was quantified as numbers of squares cleared. Three artificial diets, having 3, 4, and $7 \%$ AFDM:WM (\% AFDM/WM), were tested. These ratios fell within the natural range of values we found for North Carolina seaweeds. In these assays, we used 4 adult $A$. longimana per replicate container $(n=28)$ for each of the three treatment diets. Amphipods were fed for $2.5 \mathrm{~d}$.

Long-term experiments. The value of algal foods for Ampithoe longimana was assessed also by culturing amphipods to adulthood on various seaweeds alone, in combination, or alternately through time (explained below). These experiments quantified the effects of diet on amphipod fitness, measured as survivorship, growth, and fecundity. For these experiments, gravid females were collected from the flow-through cultures described above, individually placed in small petri dishes for $7 \mathrm{~d}$, and allowed to hatch their eggs. During this time, females and newborns were allowed to feed on Enteromorpha spp., and Sargassum filipendula. Then, newborns were collected and randomly assigned to one of the diet treatments, or to a starvation treatment receiving no food. Data on baseline mortality, unrelated to diet, were obtained from this starvation treatment. Newborn amphipods were placed individually in small petri dishes and monitored daily. For each sibling group, 1 to 3 of the amphipods that were not used in the experimental treatments were measured to obtain an initial size for that sibling group. Amphipods were measured from the rostrum to the last large coxa under a dissecting microscope.

To reduce the probability of small amphipods getting trapped in the surface tension, which can enhance the risk of mortality (Duffy \& Hay 1991a, Cruz-Rivera \& Hay 2000a), we dusted the surface of the water in the petri dishes with cetyl alcohol (Sigma). This compound breaks the surface tension and is not toxic to the animals. Amphipods were fed ad libitum. Water in the petri dishes was changed every 2 to $3 \mathrm{~d}$, and the dishes were scrubbed to eliminate fecal pellets that could serve as alternative foods, and to reduce the growth of microbes that potentially could be pathogenic.

Two long-term experiments were conducted using these general methods. For the first experiment, we tested 20 treatments simultaneously (with $\mathrm{n}=20$ for each treatment). Because most of the females produced less than 20 offspring, newborns from 2 females were pooled before being randomly assigned to each treatment. However, only 1 sibling per treatment was used from each of these pooled groups. This first experiment tested the effects of different algae on the fitness of Ampithoe longimana when the alga was offered alone versus in combination with other species. Algae that were offered in combination were selected according to their occurrence in the field; only seaweeds that consistently occurred together at one or more field sites were offered simultaneously to the 
amphipods. We used either clean algal parts or pieces of algae from which all macroscopic epiphytes were removed carefully before being offered to the amphipods. Food algae were renewed every 2 to $3 \mathrm{~d}$. This first experiment was conducted during fall (October), when herbivorous fish were lower in numbers and algal species that typically occur during winter began to recruit. Because A. longimana occurs throughout the year, but the algal communities in which it lives change seasonally (Duffy \& Hay 1991a, 1994), potential foods change with season. Conducting the experiment during the fall, when summer and winter species overlap, increased the number of algal species that we could offer the amphipods.

We cultured amphipods on the green algae Enteromorpha intestinalis, Chaetomorpha linum, Cladophora sp., Codium fragile, and Ulva curvata; the red algae Chondria dasyphilla, Gracilaria tikvahiae, Hypnea musciformis, and Spyridia filamentosa; the brown algae Dictyota menstrualis, Ectocarpus siliculosus, Fucus vesiculosus, Padina gymnospora, Rosenvingea orientalis, and Sargassum filipendula; on a starvation treatment that received no food, and on 4 algal mixtures: green algae (all green species except $C$. linum), red algae (all red species except $C$. dasyphilla), brown algae (all brown species except $F$. vesiculosus), and a combination of green, red, and brown seaweeds (GRB algae: E. intestinalis, C. fragile, U. curvata, C. dasyphilla, H. musciformis, G. tikvahiae, D. menstrualis, E. siliculosus, P. gymnospora, R. orientalis, and S. filipendula).

The second long-term experiment addressed the consequences of temporally alternating higher and lower quality foods for amphipod fitness. Ampithoe longimana is relatively sedentary (Duffy \& Hay 1994), but it can move among hosts, most commonly at night (E. Sotka pers. comm.). In this assay, we addressed how being confined sequentially with different algae affected amphipod fitness. Every $24 \mathrm{~h}$, food algae were replaced with either pieces of the same alga the amphipods were consuming, or with an alternative alga. In those treatments where amphipods were fed on alternating hosts, only 2 algal species were alternated. A. longimana were cultured either on: (1) a starvation treatment; (2) 1 of 3 algae offered alone (Codium fragile, Enteromorpha intestinalis, or Sargassum filipendula); (3) these 3 algae offered simultaneously at all times; and (4) 3 treatments with alternating diets (Enteromorpha/Codium, Enteromorpha/Sargassum, and Sargassum/Codium); for a total of 8 treatments. Thus, this experiment measured amphipod fitness if amphipods were to switch among host algae of the same species, or among different hosts, daily. The mixed algal treatment gave information on amphipod fitness when the amphipods were free to mix algal foods without being constrained to remain on one diet for $24 \mathrm{~h}$. Our selection of algal diets for this experiment was based on amphipod feeding choices as well as performance data from the first long-term experiment.

In both long-term experiments we monitored amphipods daily, recording survivorship, growth (only at certain intervals), and fecundity. Survivorship in each treatment was analyzed until the day the first female ovulated in any of the treatments. This was necessary because females were killed at ovulation to measure fecundity (egg numbers and size). Growth (in $\mu \mathrm{m} \mathrm{d}^{-1}$ ) was calculated by measuring individuals at the time of death, subtracting the initial size (see above), and dividing the total by the number of days lived in the experiments. Growth early in our assays may have resulted from previous feeding while still in the petri dishes with the females, rather than as a function of our experimental diets. Thus, for our analyses we considered only those individuals that survived beyond the day the last amphipod in the starvation treatments died. A few individuals could not be measured accurately because of microbial degradation; these were excluded from the analyses.

At ovulation, females were fixed in formalin, measured, and size $(\mu \mathrm{m})$ and growth $\left(\mu \mathrm{m} \mathrm{d}^{-1}\right)$ were calculated. The females were beheaded to extract eggs from the brood pouch. We quantified the number of eggs produced (i.e., clutch size), and measured length and width of individual eggs to calculate egg volumes, using the formula for the volume of a spheroid. For each female, volumes of individual eggs ( $\mu$ l) were added to obtain total clutch volumes, and averaged to obtain mean egg volumes per female. During the first long-term experiment, time constrains imposed by processing a large number of amphipods each day forced us to preserve females for 3 to $4 \mathrm{wk}$ before fitness parameters could be measured. In the second long-term experiment, we processed females immediately after ovulation.

Statistical analyses. The multiple-choice feeding assay was analyzed with a Friedman's test, followed by pairwise comparisons (Conover 1980). No-choice feeding assays, growth data, female sizes at ovulation, clutch sizes, and egg and clutch volumes were analyzed with 1-way ANOVA followed by Tukey's Honestly Significant Difference (HSD) tests. Before these parametric tests, homogeneity of variances was tested using $F_{\max }$ tests. When necessary, data were log or square root transformed. In one case, an outlier was detected using Dixon's test (Sokal \& Rohlf 1981), and not included in the analysis. However, data shown in the graphs include the outlier for completeness. Survivorship data were analyzed using chi-square analyses for main effects and groupings. Linear regressions were used to analyze: (1) how amphipod 
feeding and fitness related to different algal traits, (2) relations between pairs of algal traits, and (3) relations between amphipod fitness traits. We used mean values per treatment when relating amphipod feeding or fitness variables to algal traits (e.g., when relating amphipod feeding rate to algal protein) because there was no logical pairing between the 2 data sets. However, when regressions were performed on pairs of algal or amphipod traits (e.g., algal protein versus nitrogen, amphipod female size versus number of eggs, etc.) data were matched by sample of origin or by individual.

\section{RESULTS}

\section{Algal traits}

Measurements of algal toughness and nutritional quality (Fig. 1) allowed these traits to be related to feeding and fitness of Ampithoe longimana. Significant differences were found among algae for all parameters measured (for all analyses p $<0.001$, 1-way ANOVA; Fig. 1). Patterns of nutrient content among algae changed considerably depending on whether values were expressed as percentages of dry (Fig. 1a
Values Per Dry Mass
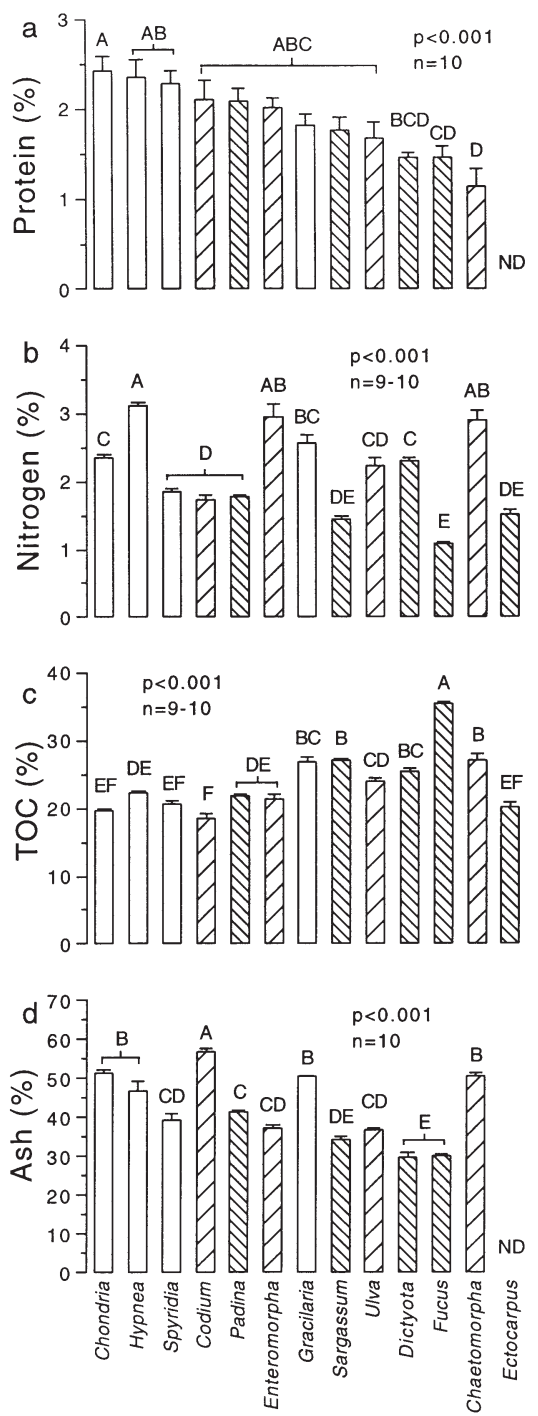

Values Per Wet Mass
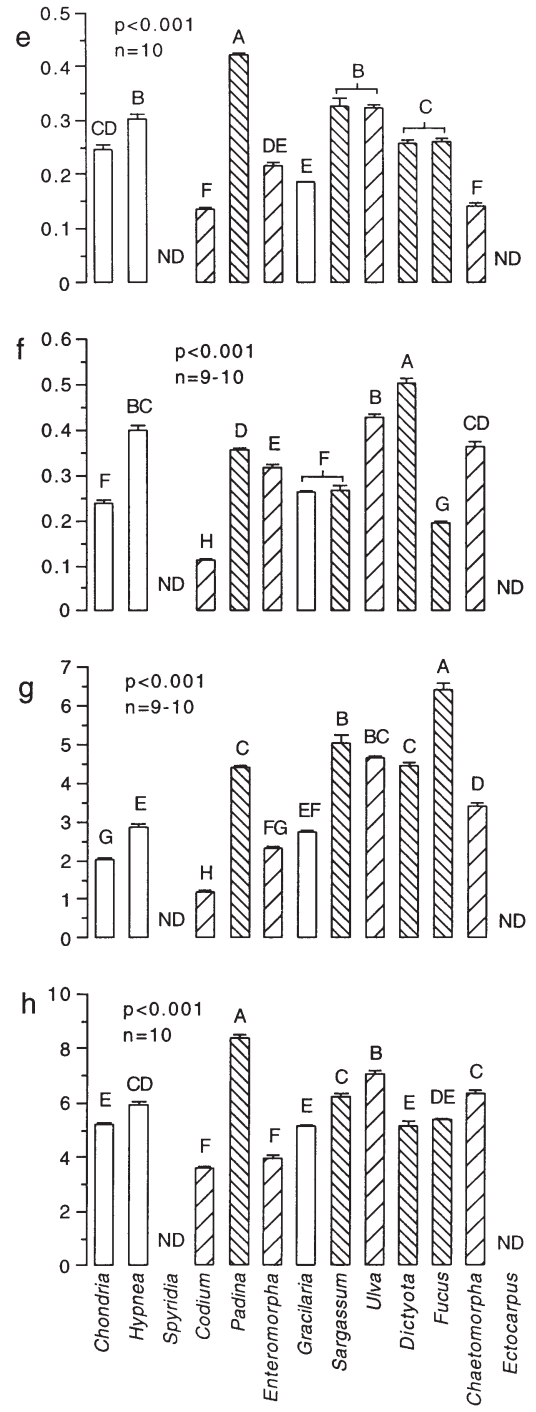
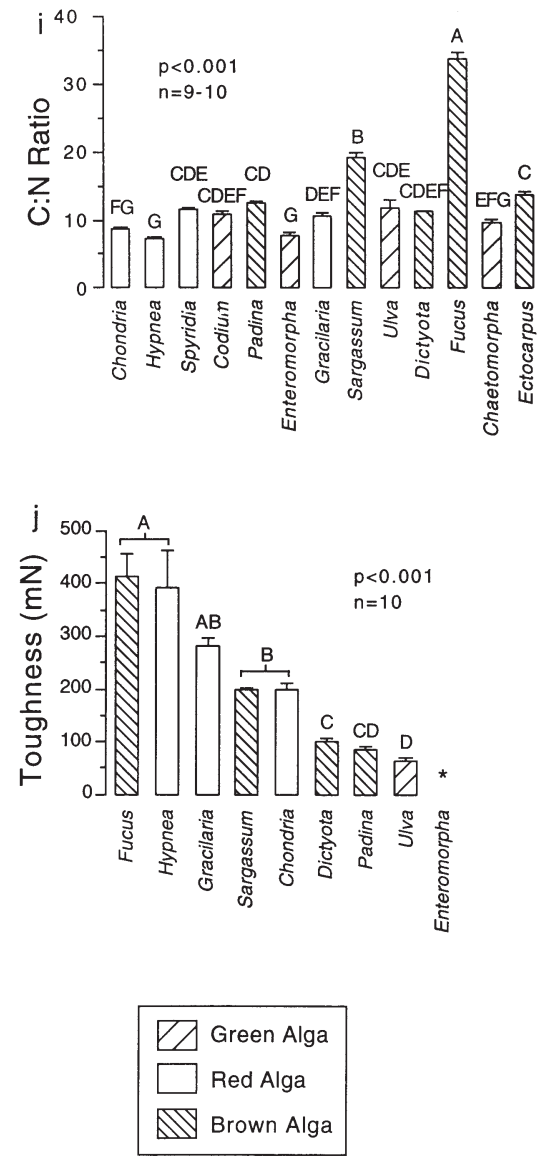

Fig. 1. Nutritional and physical traits of algae from North Carolina. Bars represent means +1SE. All analyses are by ANOVA followed by Tukey's HSD for significant groupings. Same letters above bars indicate no significant differences among treatments. $\mathrm{ND}=$ no data (see methods). Toughness (j) was only measured on algae with bladed or branched morphologies having continuous outer layers (see methods). For Enteromorpha intestinalis $\left({ }^{*}\right)$, toughness was below the minimum resistance (force) we could quantify 
to d) or wet (Fig. 1e to h) mass. Although samples generating these data were collected over a $55 \mathrm{~d}$ period spanning the time course of our assays, within-species variance in these traits was very low compared to variance among species. Thus, the among-species variance we were focusing on in our assays is unlikely to have been masked by variance within species.

When expressed as percentage of dry mass, algal protein (Fig. 1a) was highest among 3 of the red algae (Chondria dasyphilla, Hypnea musciformis, and Spyridia filamentosa), followed by the green alga Codium fragile, the brown alga Padina gymnospora, and the green alga Enteromorpha intestinalis. Intermediate values were obtained for Gracilaria tikvahiae, Sargassum filipendula, and Ulva curvata. However, none of these algae were statistically different in protein content per dry mass. In fact, Chondria (the alga with the highest protein by dry mass) was statistically equivalent to all algae except Dictyota menstrualis, Fucus vesiculosus, and Chaetomorpha linum, which had the lowest protein content of all seaweeds. In contrast with these patterns, when protein was expressed as percentages of wet mass (Fig. 1e), Padina had the highest protein content and was statistically different from all other species. Similarly, Sargassum and Ulva, which ranked 8 and 9 (respectively) in protein content per dry mass, ranked 2 and 3 when protein was expressed by wet mass. The lowest protein content per wet mass was found in Codium although this species had the fourth highest concentration of protein per dry mass.

As with protein, nitrogen concentration varied significantly among algae both as percentages of dry or wet mass (Fig. 1b,f). Nitrogen per dry mass was highest in Hypnea, Enteromorpha, Chaetomorpha, and Gracilaria, and lowest in Ectocarpus, Sargassum and Fucus (Fig. 1b). In contrast, nitrogen content per wet mass was highest in Dictyota, followed by Ulva, Hypnea and Chaetomorpha, and lowest in Chondria, Fucus, and Codium. Interestingly, we found no correlation between nitrogen and protein content of the algae $\left(n=115, r^{2}=0.007, p=0.362\right)$.

TOC differed significantly among algae, with patterns showing some similarity for both dry and wet mass (Fig. 1C,g). TOC was highest in Fucus vesiculosus and lowest in Codium fragile, with brown algae tending to be somewhat higher in carbon content than green and red algae. Only Gracilaria tikvahiae and Padina gymnospora differed considerably in carbon content depending on whether dry or wet masses were used.

Ash content per dry mass was highest in Codium, followed by Chondria, Chaetomorpha, Gracilaria, and Hypnea (Fig. 1d). However, when expressed as percentage of wet mass (Fig. 1h), ash content was the low- est in Codium. In contrast to values per dry mass, Padina had the highest percentage of ash per wet mass, followed by Ulva, Chaetomorpha and Sargassum (Fig. 1h). Although red algae tended to have more ash per dry mass than brown algae (Fig. 1d), differences in ash were less marked among these 2 algal groups (with the exception of Padina) when water content of the algae was taken into account (Fig. 1h).

Nutritional value of a food is a function of both total amounts of nutrients, and relative balance among different nutrients. We, thus, calculated the carbon to nitrogen ratio for the 13 seaweeds used (Fig. 1i). Fucus vesiculosus had a significantly higher $\mathrm{C}: \mathrm{N}$ ratio than all other algae (being 1.7 to 4.4 times greater). C:N ratio in Sargassum filipendula was lower than in Fucus, but higher than in all other seaweeds. Hypnea musciformis and Enteromorpha intestinalis had lower $\mathrm{C}: \mathrm{N}$ ratios than most algae. Differences among other species were small and generally not statistically significant (Fig. 1i).

Toughness of seaweeds was approximated using a penetrometer. Due to the constraints of this methodology, toughness (Fig. 1j) could only be measured on foliose and some branched algae (see methods). Algal toughness differed as much as 7 -fold among species, with Fucus vesiculosus and Hypnea musciformis being considerably more resistant to piercing than all other species but Gracilaria tikvahiae (Fig. 1j). Sargassum filipendula and Chondria dasyphilla had similar toughness as Gracilaria, but were significantly more resistant to piercing than Dictyota, Padina, and Ulva. Although thalli of Enteromorpha intestinalis were broad enough to be tested with our penetrometer, none of the thalli sampled were more resistant than the minimum force exerted by the device $(28 \mathrm{mN})$. Thus, we could not measure toughness accurately for this alga, but it was considerably less resistant to piercing than any of the other species measured.

\section{Feeding assays}

When presented simultaneously with 8 common macroalgae, Ampithoe longimana preferred Dictyota menstrualis and Padina gymnospora, followed by Codium fragile, over all other algae $(\mathrm{p}<0.001$, Friedman's test; Fig. 2a). A. longimana consumed 50 to $90 \%$ more of $D$. menstrualis and P. gymnospora than of any other species. Variance in consumption of $C$. fragile was high and amount eaten was not significantly different from that on any other species.Consumption of algae in the no-choice assay differed significantly among diets $(\mathrm{p}<0.001,1$-way ANOVA; Fig. $2 b)$ and provided a contrast with the choice assay (Fig. 2a). When amphipods were confined with only one alga, 


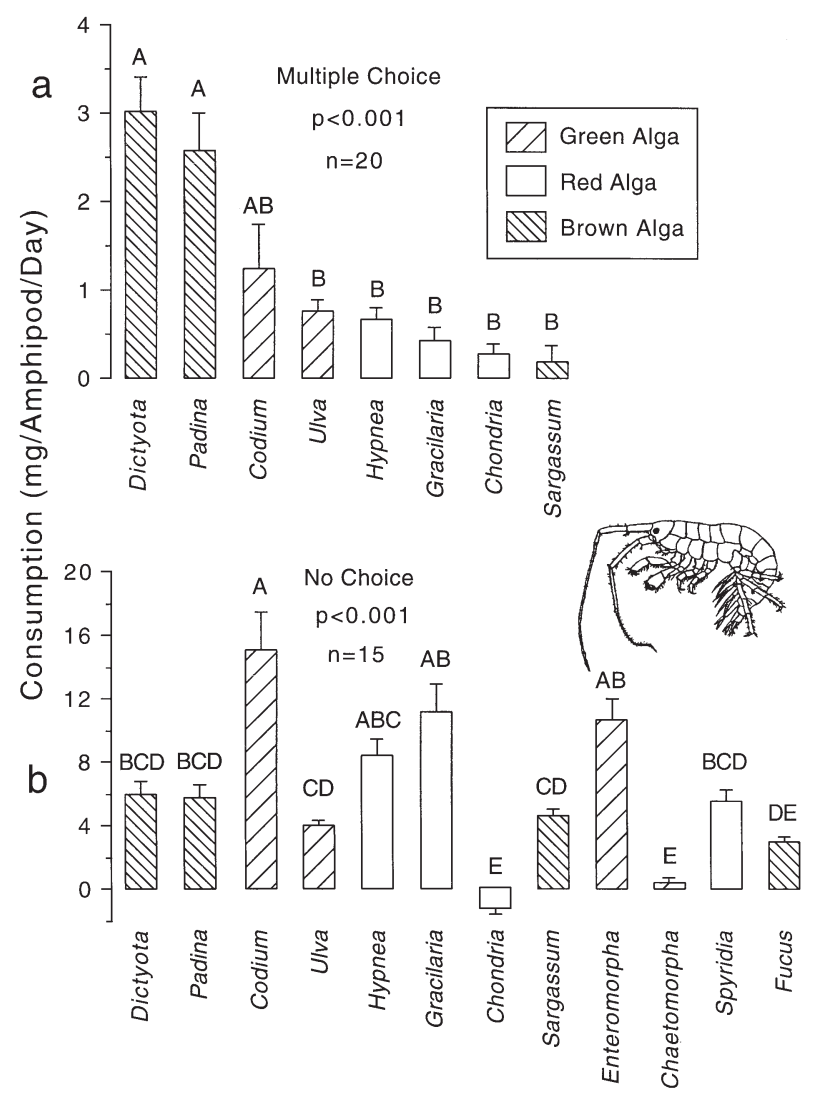

Fig. 2. Ampithoe longimana. Feeding when given (a) a simultaneous choice of 8 seaweeds, or (b) when offered only 1 of 12 algal species. Bars represent means + 1SE. Analyses are (a) by Friedman's test followed by Friedman's multiple comparisons tests, or (b) by 1-way ANOVA followed by Tukey's HSD. Same letters above bars indicate no statistical differences among those means consumption was highest on Codium fragile, followed by Gracilaria tikvahiae, Enteromorpha intestinalis, and Hypnea musciformis. These algae were of intermediate to low preference in the choice assay. The species that were eaten most in the choice assay (Dictyota and Padina) were consumed at intermediate rates in this assay. These patterns suggest compensatory feeding, with the best foods meeting herbivore needs after modest levels of consumption, and algae of lesser quality needing to be consumed at greater rates to meet these needs. Consumption of other algal species was generally intermediate with the exception that consumption of Chaetomorpha linum and Chondria dasyphilla did not differ significantly from zero.

We used regression analyses to relate amphipod feeding rates to measurements of algal quality. Because we could not show that Chaetomorpha and Chondria were treated as foods by Ampithoe longimana (i.e., amounts eaten did not differ from zero), we limited our analyses to those species that were eaten. Because ash content is reciprocal to AFDM, we did not relate feeding rates with algal ash concentrations.

Amphipod feeding rates were not related to algal toughness, C:N ratio, or with protein, nitrogen, TOC, or AFDM of the algae when expressed as percentages of dry mass. However, when food quality measurements were expressed as percents of wet mass, there was a strong negative relationship between TOC and amphipod feeding rates $\left(n=9, r^{2}=-0.918, p<0.001\right)$. Similarly, there was a strong negative relationship between feeding rates and AFDM:WM ( $\mathrm{n}=9, \mathrm{r}^{2}=$ -0.929 , p < 0.001; Fig. 3a). Both TOC and AFDM:WM were measures of algal organic content, and were
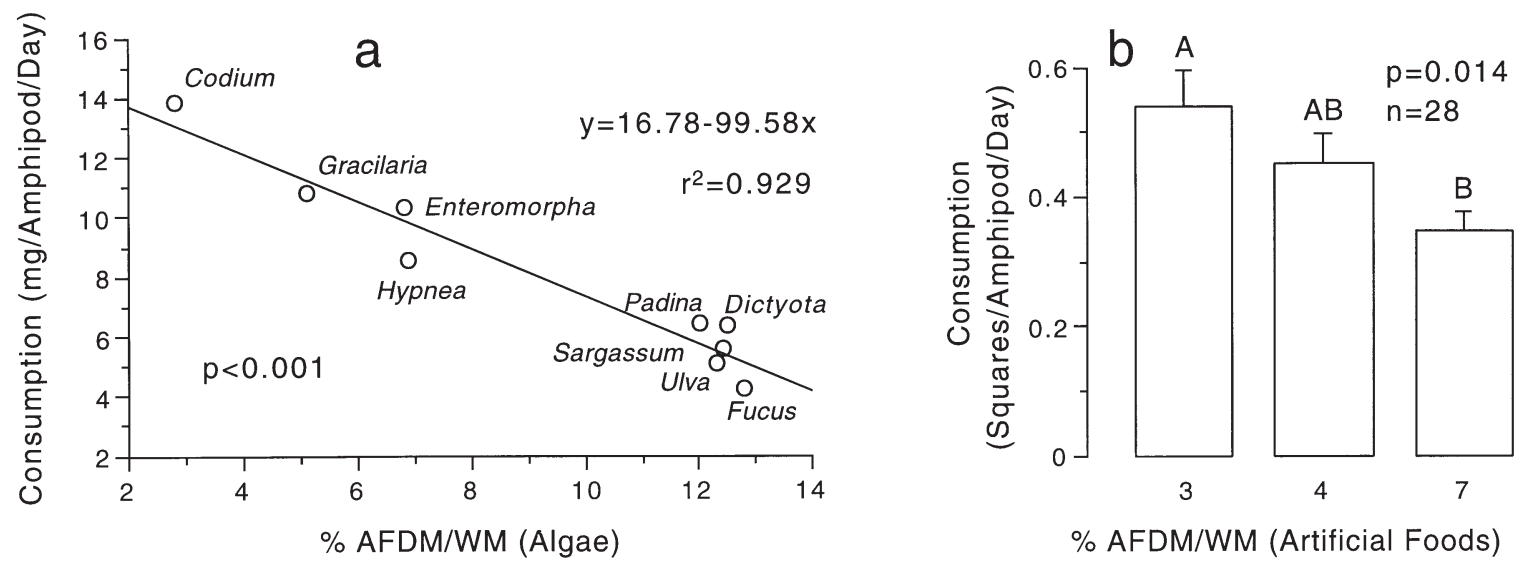

Fig. 3. Ampithoe longimana. Compensatory feeding related to mean AFDM:WM of (a) algae, and (b) artificial foods. Feeding rates (means) on (a) individual algae are adapted from Fig. 2b (also see 'Methods') for those species on which amphipod consumption was different from zero (with the exception of Spyridia filamentosa, for which we had no data on AFDM:WM; see 'Methods'). Amphipods were fed (a) on each algal species alone, or (b) on 1 of 3 artificial diets offered alone. Bars represent means + 1SE. Analyses are (a) by linear regression or (b) 1-way ANOVA followed by Tukey's HSD. Same letters above bars indicate no significant differences between treatments 
positively correlated $\left(n=9, r^{2}=0.864, p<0.001\right)$. A weaker, but statistically significant, negative relationship was found between consumption and protein per algal wet mass $\left(\mathrm{n}=9, \mathrm{r}^{2}=-0.546, \mathrm{p}=0.023\right.$ ). Feeding was not related with algal nitrogen content $\left(\mathrm{n}=9, \mathrm{r}^{2}=\right.$ $0.217, \mathrm{p}=0.206)$. Protein content, but not nitrogen, was related positively with algal organic content $\left(n=9, r^{2}=\right.$ 0.549, $\mathrm{p}=0.022$ ), partially accounting for the observed patterns.

These results suggest that Ampithoe longimana exhibits compensatory feeding. As the concentration of total organic matter in the algal tissue (reward per bite as a function of wet mass) declines, the amphipod consumes more, substituting quantity for quality. This hypothesis was confirmed when replicate groups of $A$. longimana fed on artificial diets that varied only in their concentration of organic matter, but not in the components of the food (Fig. 3b). As with the no-choice assay using algae, Ampithoe feeding increased significantly ( $p=0.014,1$-way ANOVA; Fig. 3b) as the concentration of organic matter in our artificial foods decreased.

\section{Long-term experiments}

Our first long-term experiment quantified the fitness of Ampithoe longimana when feeding on single species versus algal mixtures (Figs 4 \& 5). Although mixed diets were beneficial over some single species diets, fitness of Ampithoe in all the mixed treatments was matched by fitness on some of the monospecific diets (Fig. 4b). A large number of the 20 treatments tested produced amphipods having similar survivorship, growth and fecundity, suggesting that compensatory feeding by this amphipod (Figs $2 b$ \& 3 ) can offset some of the disadvantages of feeding on algae of lower organic or nutrient content (e.g., Enteromorpha and Hypnea; Figs 1 \& 3a). However, compensatory feeding did not offset the limited food value of all algae. Amphipods confined with Codium and Gracilaria had, or tended to have, lower survivorship and/or growth (Fig. 4). Interestingly, survivorship and growth were reduced for amphipods fed on Ulva curvata (Fig. 4). This alga had relatively high nutrient content (Fig. 1), but was a relatively low preference food (Fig. 2a).

When the first females became ovigerous (13 d), survivorship of Ampithoe longimana on most diets was high, although there were significant differences among some treatments $(p<0.001$, chi-square tests; Fig. 4a). The highest survivorship tended to be on algal mixtures (Red algae, Brown algae, and GRB algae), but survivorship on mixtures was statistically indistinguishable from survivorship in all but 6 of the other treatments (Fig. 4a). Survivorship was $70 \%$ or higher in 13 of the 20 treatments we used, and average survivorship for these 13 treatments was $85 \%$. Thus, Ampithoe survived well on most of the diets we offered. Survivorship was intermediate (50 to $60 \%$ ) on Ulva curvata, Codium fragile, and Gracilaria tikvahiae, although consumption of both Codium and Gracilaria was high when these algae were offered alone (Figs $2 b$ \& 3a), and survivorship on these three algae was statistically indistinguishable from survivorship on most diets (Fig. 4a). By 12 d, Chaetomorpha linum, Chondria dasyphilla, Cladophora sp., and the starvation treatment produced no survivors (Fig. 4a). However, amphipods on Cladophora lived longer than starved conspecifics, or of those confined with Chaetomorpha and Chondria.

Growth was affected significantly by diet $(\mathrm{p}<0.001$, 1-way ANOVA, Fig. 4b), with amphipods in some treatments growing almost seven fold faster than those in other treatments. Growth tended to be high in the 4 algal mixtures, but these treatments did not differ significantly from growth on 3 to 9 of the monospecific algal treatments. Growth on Enteromorpha, Padina, Rosenvingea, Dictyota, Gracilaria, Spyridia, Hypnea, and Fucus was similar (Fig. 4b), in spite of large differences in nutritional traits and toughness among some of these algae (Fig. 1). Ulva, Codium, and Cladophora produced minimal growth; these diets also suppressed survivorship. Neither survivorship nor growth were correlated significantly with any of the algal nutritional parameters we quantified.

For females, we measured growth, length at ovulation, days to ovulation, clutch size (eggs per female), volume of individual eggs, and total volume of the clutch (Fig. 5). In this first long-term assay, data were collected using females that were preserved and stored prior to measurements. Because eggs swell some when preserved, volumes of eggs and clutches are larger than would occur naturally. However, our interest was in relative, rather than absolute, measurements of egg volume among treatments. Within approximately $1 \mathrm{mo}$ (from birth to the end of the experiment), all surviving females ovulated, except for 1 female in each of the Ulva and the Sargassum treatments. Codium (a diet that suppressed survivorship and growth, Fig. 4) produced no females. Given the higher mortality in this diet, and the large number of treatments used, it is possible that no females were assigned to this diet when amphipods were randomly placed in the treatments, or that the few females originally placed in this treatment died within the first $2 \mathrm{wk}$ of the assay. For example, only 2 females matured in the green algal mixed diet (green algae; Figs 4 \& 5), but survivorship and growth in this treatment were high, suggesting that random placing of the females could have produced this result. 
As with growth for the entire experimental population (Fig. 4b), female growth was affected significantly by diet ( $p=0.004,1$-way ANOVA; Fig. 5a). However, post-hoc comparisons failed to detect differences among treatments ( $p>0.05$, Tukey's HSD). There were also significant differences in the size of females at
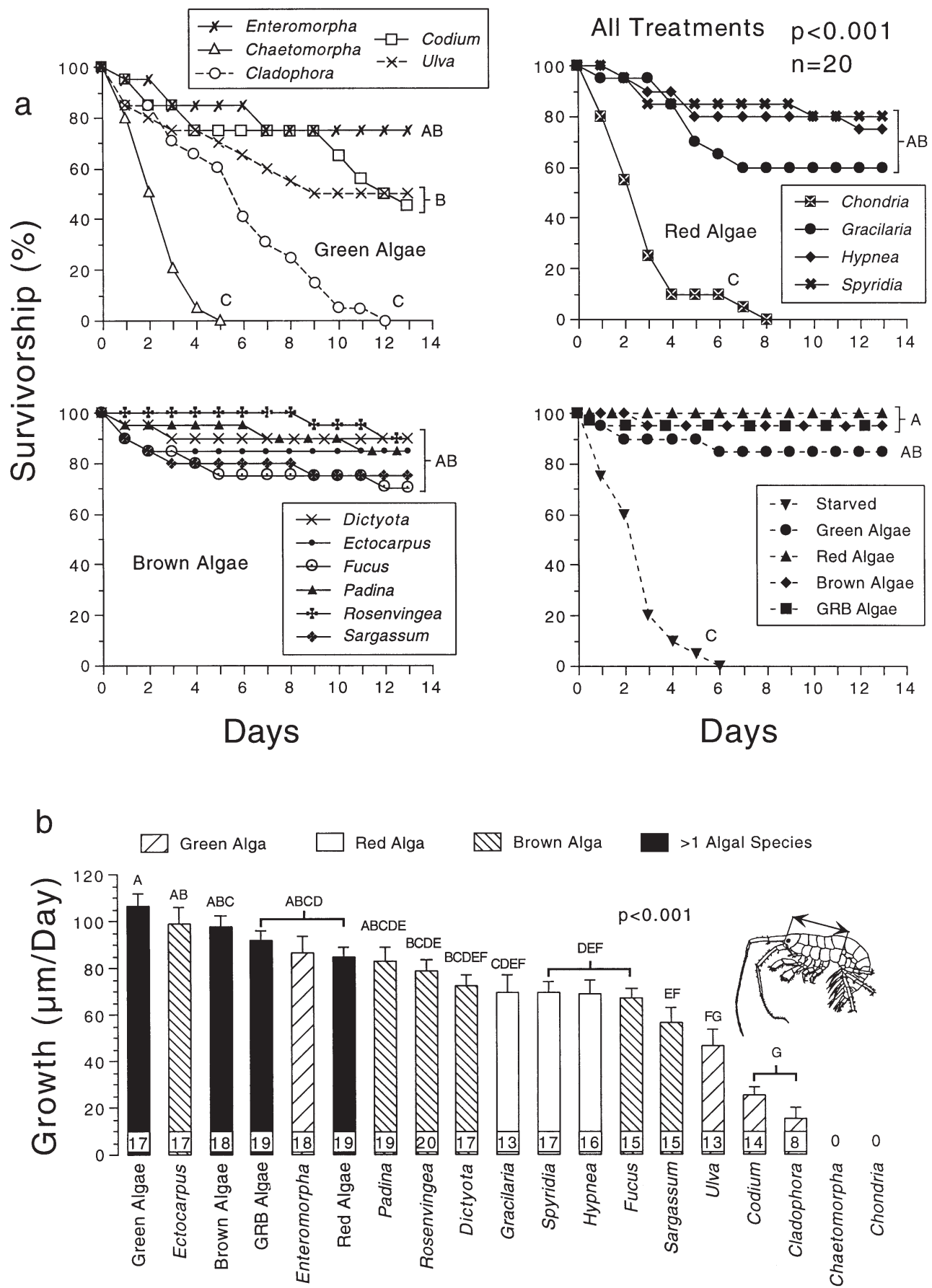

Fig. 4. Ampithoe longimana. (a) survivorship and (b) growth on algae offered alone or in selected combinations (see 'Methods') during the first long-term experiment. Amphipods were monitored daily and all treatments were run simultaneously. To enhance clarity of the figures, symbols in the survivorship plots were sometimes deleted to avoid overlap, and treatments were grouped into categories. Analyses are (a) by chi-square for main effects and significant groupings, or (b) by 1-way ANOVA followed by Tukey's HSD for multiple comparisons. Same letters to the right of survivorship plots or above bars indicate no significant difference among treatments. Amphipod growth was quantified using the length indicated by the arrows (b). Numbers at the base of the bars (mean + 1SE) indicate the number of amphipods measured per treatment 

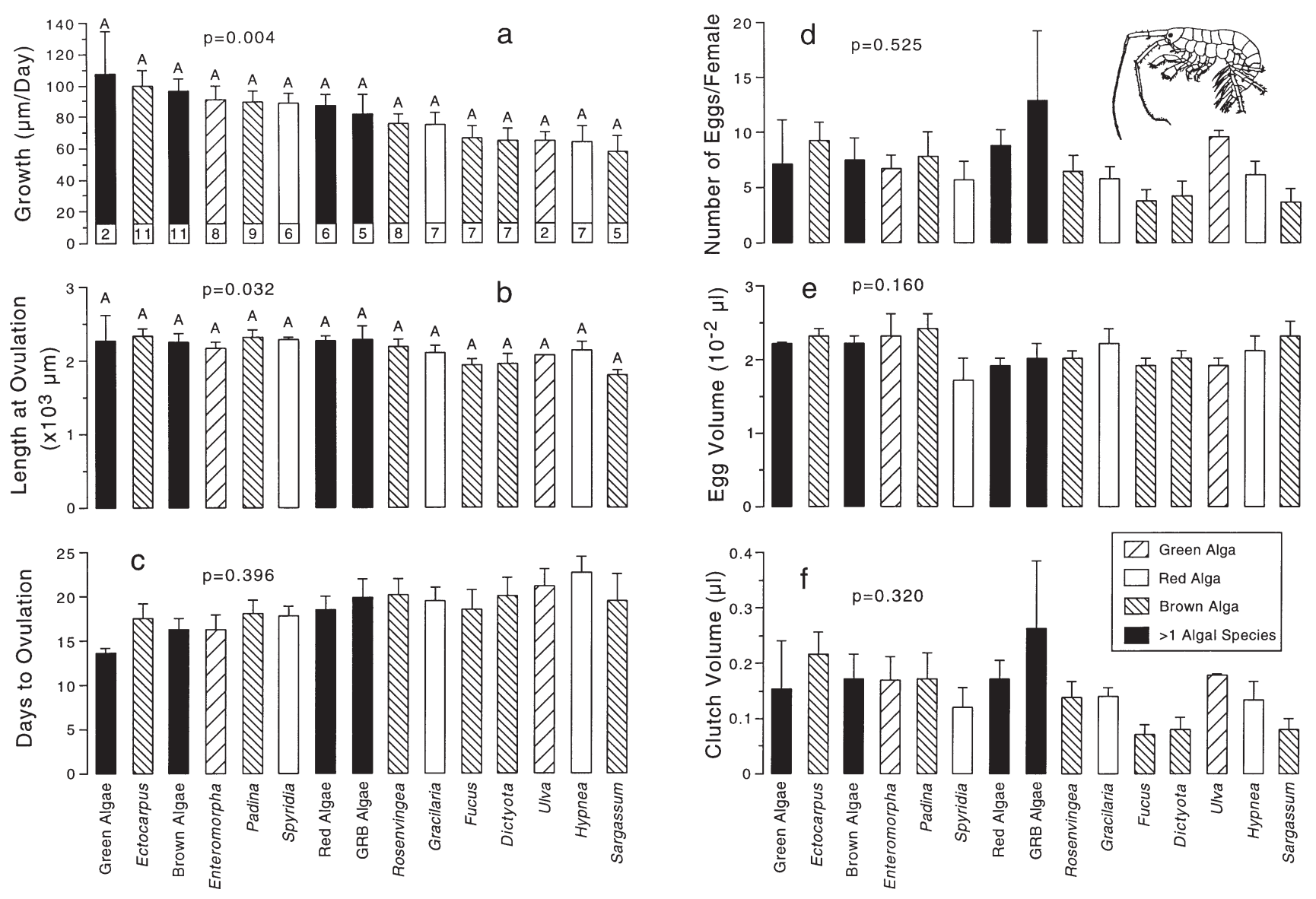

Fig. 5. Fitness parameters measured in Ampithoe longimana females from the first long-term assay. Data include all females, but statistical analyses of eggs per female (d), and clutch volume (f), do not include 1 outlier in the GRB treatment (see 'Results'). Symbols, growth measurements, and statistical analyses are as in Fig. 4b

ovulation ( $\mathrm{p}=0.032$, 1-way ANOVA; Fig. 5b), but again differences were not detected during post-hoc tests. Because the sample size of females analyzed for some diets was low, our analyses had limited statistical power. Despite significant variations in growth and size, we did not detect any dietary effects on days to ovulation, the number of eggs produced, the volume of individual eggs, or the total volume of the clutch for surviving females (Fig. $5 \mathrm{C}$ to f). A trend towards increasing days to ovulation with decreasing growth rate was observed. These 2 reproductive variables were related negatively $\left(n=101, r^{2}=-0.578, p<0.001\right)$. The large variance in clutch size and clutch volume for the treatment containing green, red, and brown algae together (GRB algae) was due to 1 female that produced 36 eggs. This female was comparable in size to most females in other diets and was treated as an outlier (after Dixon's test). Analyses (Fig. 5d,f) did not include this female but it is included in the graphs for completeness.

Based on the results from the first long-term assay, we ran a second long-term experiment with alternat- ing diets. Amphipods were fed on one high quality alga (Enteromorpha intestinalis, which produced high survivorship and growth), one of intermediate value (Sargassum filipendula, which produced high survivorship but lower growth), and one of low value (Codium fragile, which suppressed survivorship and growth) either alone, in combination, or in alternating pairs of species (every $24 \mathrm{~h}$ ). Survivorship in this experiment was high $(\approx 85 \%)$ and statistically indistinguishable for all fed treatments; survivorship in the starvation treatment declined to zero by Day 6 (Fig. 6a). In contrast to the patterns for survivorship, growth was affected significantly by diet in the fed treatments $(\mathrm{p}<$ 0.001, 1-way ANOVA; Fig. 6b). Growth was highest when amphipods had simultaneous access to all 3 algae, but equivalent to that on Enteromorpha alone. Growth was intermediate on the alternating diet treatments (Enteromorpha/Codium, Enteromorpha/Sargassum, and Sargassum/Codium). Growth on Sargassum and Codium alone tended to be low, although amphipods on Sargassum grew significantly more than those on Codium (Fig. 4b). When Ampithoe longimana 


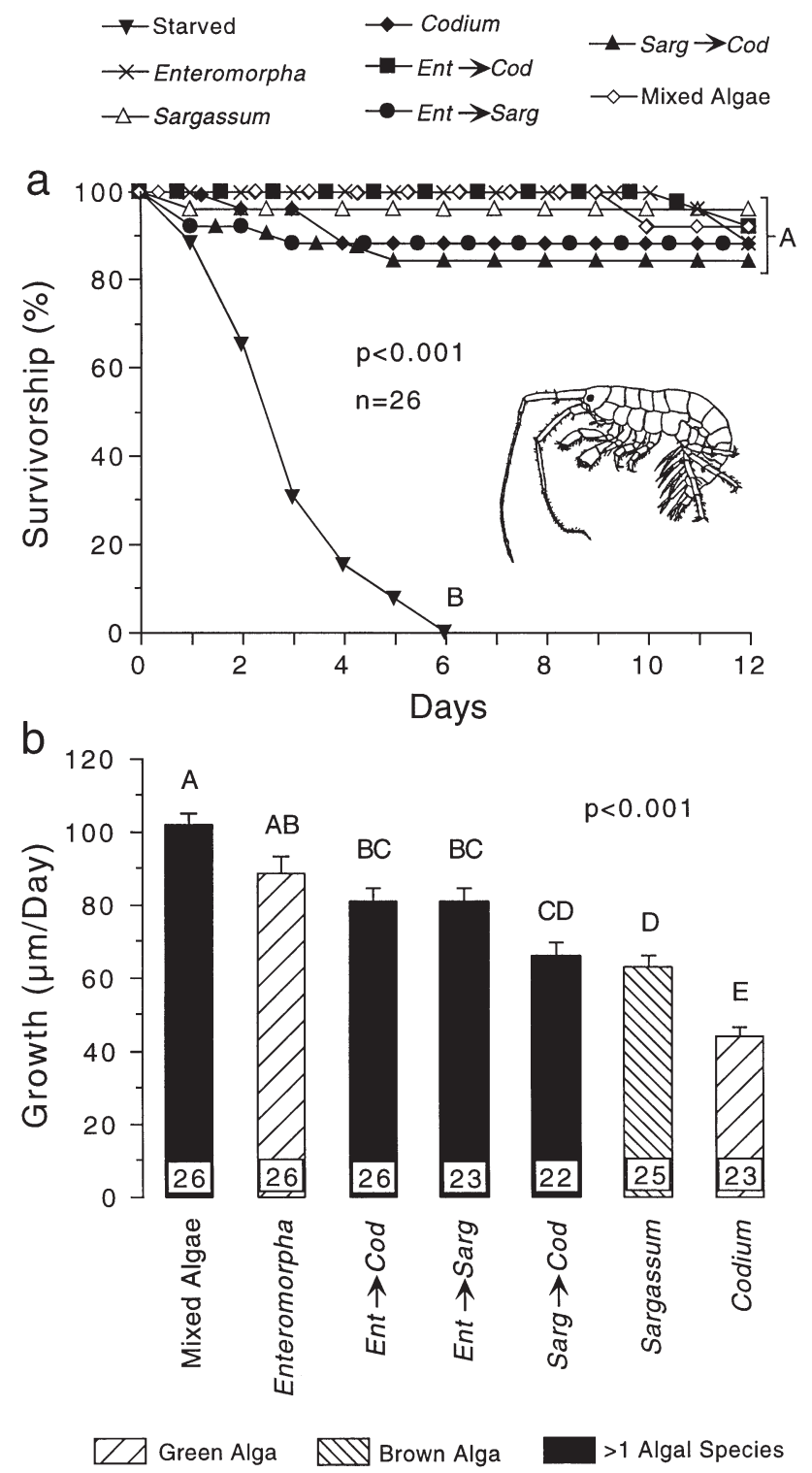

Fig. 6. Ampithoe longimana. (a) survivorship and (b) growth on single, combined, or alternating algal foods (second long term experiment; see 'Methods'). Mixed algae included Enteromorpha (Ent), Codium (Cod), and Sargassum (Sarg) simultaneously. Treatments in which foods were alternated (every $24 \mathrm{~h}$ ) are shown by the arrows. All analyses, growth measurements, and symbols not explained in legends are as in Fig. 4

fed on pairs of alternating diets, growth was similar to that on the better quality alga. Thus, growth on Enteromorpha alone was equivalent to that in both the Enteromorpha/Codium, and the Enteromorpha/Sargassum treatments, whereas growth in the Sargassum/Codium treatment was equivalent to that on Sargassum alone.

In this assay, of the 5 females feeding on Codium alone, 3 produced eggs (Fig. 7a). In the other fed treat- ments, all females ovulated. As we found in the first long-term assay (Figs $4 \mathrm{~b} \& 5 \mathrm{a}$ ), growth of females during this second long-term experiment was affected by diet $(\mathrm{p}<0.001,1$-way ANOVA; Fig. 7a), and closely paralleled growth for the entire experimental population (Fig. 6b). The size of females at ovulation also was affected significantly by diet $(p=0.007,1$-way ANOVA; Fig. 7b), but differences among treatments were small and undetectable during post-hoc tests ( $p$ > 0.05, Tukey's HSD). This was similar to our findings from the first long-term assay (Fig. 5b). Females that had simultaneous access to three macroalgae (mixed algae) became ovigerous significantly ( $p=0.006$, 1-way ANOVA; Fig. 7c) sooner than on either Sargassum or Codium alone; all other treatments were intermediate and statistically indistinguishable from all other diets (Fig. 7c). We also found an inverse relation between growth and days to ovulation in this assay. Diet, could not be shown to affect the number of eggs per female, the volume of individual eggs, or the total volume of the clutch for those females producing eggs (Fig. 7d,e,f). The number of eggs per females differed as much as 3.5-fold among treatments, but variance among all diets was large.

\section{DISCUSSION}

Seaweeds used in this study represented a broad range of life histories and morphologies (Schneider \& Searles 1991) and also varied considerably in nutritional traits and toughness (Fig. 1). In spite of this, Ampithoe longimana was able to compensate for many differences among algae by increasing consumption rates of seaweeds with lower food value per volume (Figs $2 \mathrm{~b} \& 3 \mathrm{a}$ ). A. longimana, thus, utilized a variety of algae without experiencing large negative effects on fitness (Figs 4 \& 5). Algal nutrients did not correlate with amphipod feeding choices (Fig. 2a), and simultaneous access to algae in mixtures did not enhance fitness relative to some monospecific diets (Figs 4, 5, $6 \& 7$ ), although some effects of sequentially mixing diets were noted (Figs 6 \& 7).

Ampithoe longimana significantly preferred Dictyota and Padina over all other algae except Codium (although mean consumption of this alga was noticeably lower; Fig. 2a). Dictyota had higher nitrogen than other algae (Fig. 1f), and Padina had higher protein (Fig. 1e), however, neither nutrient related well with food choice when all seaweeds were taken into consideration. Moreover, Codium had the lowest nutrient content of all algae, but consumption of this alga was statistically equivalent to that of all other algae (Fig. 2a). Although toughness could be measured only for certain seaweeds (Fig. 1j), it did not relate strongly 

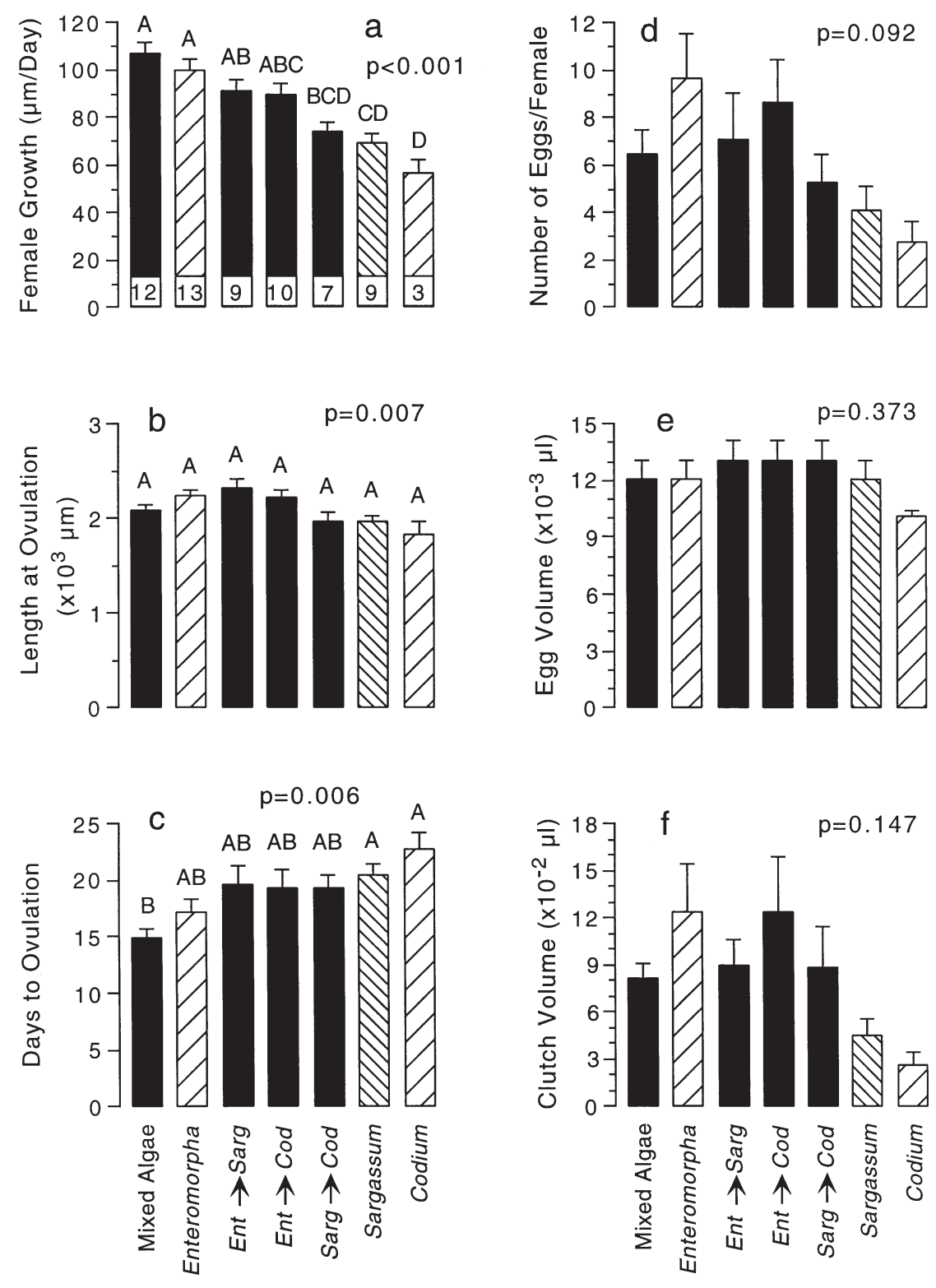

Fig. 7. Ampithoe longimana. Fitness parameters (means +1SE) of females during the second long-term assay. Analyses are by 1-way ANOVA followed by Tukey's HSD when required. Other symbols and designations are as in Fig. 6b

with the morphology of the algae. For example Fucus and Hypnea, and Sargassum and Chondria had very similar resistances to piercing, but 1 species in each pair has a flattened foliose thallus (or flattened 'leaves' as in Sargassum) and the other has a branching cylindrical thallus (Duffy \& Hay 1991a, Schneider \& Searles 1991). Plant and algal toughness and morphology are important for the feeding choices of both terrestrial and marine herbivores (Pennings \& Paul 1992, Kennish \& Williams 1997, Pennings et al. 1998, and references therein); however, Ampithoe longimana does not ap- pear to cue strongly on these traits for food selection (Figs 1j \& 2a).

In contrast to feeding preferences, feeding rates of Ampithoe longimana when confined with different algae (no-choice assays; Fig. 2b) related well to some algal traits (Fig 3, see also 'Results'), but only when nutritional measurements took into account the water content of algae. Although researchers have often related herbivore feeding to food quality of seaweeds expressed as nutrients by dry mass (e.g., Neighbors \& Horn 1991, Cronin \& Hay 1996a,b, Kennish \& Williams 1997, Wakefield \& Murray 1998, Poore \& Steinberg 1999), we found this approach inadequately explained our results. When confined with single species of algae, A. longimana showed compensatory feeding on algae that had lower protein, TOC, and AFDM per wet mass (Fig. 3a, see also 'Results'). Compensatory feeding was also found when amphipods were confined with single artificial diets that varied only in their amount of organic matter (AFDM) per wet mass within the range of natural values found for North Carolina seaweeds (Fig. 3b). Thus, consumption by A. longimana increased as the amount of digestible organic matter in both algae and artificial diets decreased as a function of wet mass (i.e., compensatory feeding).

Although nitrogen acquisition has been proposed as a critical process for herbivore nutrition (Mattson 1980, White 1993), nitrogen was not correlated with feeding rates of Ampithoe longimana. Nitrogen also did not correlate with algal protein or organic content, potentially explaining this result. Thus, algae with high organic content or protein did not have proportionally more nitrogen than those with lower values. This lack of correlation between protein and nitrogen does not appear to be unusual for among-species contrasts of seaweeds. Previous studies also showed weak correlation, no correlation, or even negative correlation between protein and nitrogen con- 
tents of seaweeds (see Duffy \& Hay 1991a, tables in Neighbors \& Horn 1991, Kaehler \& Kennish 1996).

Compensatory feeding of marine consumers has rarely been addressed, but some herbivorous crabs appear to compensate in a fashion similar to Ampithoe longimana (Stachowicz \& Hay 1999), and compensation has been suggested to occur in other crabs, amphipods, and isopods (Morán \& Arrontes 1994, Stachowicz \& Hay 1996, Poore \& Steinberg 1999). Although nutritional compensation also can be achieved through the alteration of assimilation efficiency (Simpson \& Simpson 1990) or respiration rate (Graça et al. 1993), A. longimana clearly adjusted feeding rates in response to lower food quality (Fig. 3). Feeding rates were correlated negatively to TOC, AFDM, and protein content of the algae; however, correlation does not imply causality. Protein, for example, was correlated positively with algal organic content. If a limiting nutrient covaries along with other traits, herbivores may not need to respond to that nutrient directly for compensatory feeding, but only to recognize a trait associated with the limiting nutrient. Ampithoe responded closely to organic content in both natural and artificial foods (Fig. 3), indicating that this amphipod reacts to overall dietary dilution. Compensatory feeding in response to diluted nutrients occurs in a variety of small terrestrial and marine consumers such as slugs (Rueda et al. 1991), insects (Slansky \& Feeny 1977, Simpson \& Simpson 1990, Slansky 1993), amphipods (Cruz-Rivera \& Hay 2000a), and crabs (Stachowicz \& Hay 1999) that may be constrained in their mobility either intrinsically or by predators (Price et al 1980, Hay et al. 1987, Bernays \& Graham 1988, Hay 1992, Duffy \& Hay 1994, Hay \& Steinberg 1996, Poore \& Steinberg 1999, Stachowicz \& Hay 1999, CruzRivera \& Hay 2000a). It is possible that this feeding strategy is more common among small herbivores than is currently appreciated.

Fitness consequences of consuming individual algae (Figs 4, 5, 6 \& 7) did not strongly parallel feeding choices (Fig. 2a). Ampithoe longimana significantly preferred Dictyota and Padina over Gracilaria, Hypnea, and Ulva (Fig. 2a), however, survivorship, growth, and fecundity rarely differed significantly when feeding on these 5 seaweeds, although survivorship and growth tended to be lower on Gracilaria and Ulva (Fig. 4). Moreover, Codium ranked third in food choice, but this alga decreased survivorship in one assay (Fig. 4a), significantly suppressed growth (Figs 4b, 6b \& 7a), and delayed ovulation and tended to reduce egg production in our second long-term experiment (Fig. $\left.7_{C}, d\right)$. The volume of individual eggs and of the clutch were not affected by diet (Figs $5 \mathrm{~d}$,f \& $6 \mathrm{~d}$, f); thus, fitness differences according to size of the newborns (see Cruz-Rivera \& Hay 2000b) should not be expected.
However, we could not directly measure the viability of eggs, which for some marine herbivores can be affected by algal metabolites without reductions in egg production (Poulet et al. 1995, Chaudron et al. 1996, Miralto et al. 1999).

Chondria dasyphilla was similar in nutritional value and toughness to other seaweeds (Fig. 1); however, Ampithoe longimana did not consume this alga even when no other choices were offered (Fig. 2b). A. longimana also refused to eat Chaetomorpha (Fig. 2b). Thus, amphipods confined with either of these algae died at similar rates as starved conspecifics (Fig. 4a). It is possible that these algae are chemically or structurally defended from amphipods (e.g., Hay et al. 1998a, Schnitzer et al. 1998), but tests are needed to support this hypothesis. Survival of amphipods on Cladophora sp. was very low (Fig. 4a), but amphipods confined with this alga survived twice as long as starved conspecifics, suggesting that at least some consumption occurred.

Although compensatory feeding allowed Ampithoe longimana to maintain fitness on algae that were lower in nutritional value, this behavior was not sufficient to completely circumvent the low nutritional quality of seaweeds like Codium and probably Gracilaria (which tended to decrease survivorship; Fig. 4a). Compensatory feeding is advantageous, but it has limits. For example, using artificial diets of varying nutrient content, Cruz-Rivera \& Hay (2000a) showed that although 3 sympatric temperate amphipods responded to low food quality by increasing their feeding rates, only $A$. longimana was able to offset the negative effects of low quality foods on fitness. In this study, using natural foods, some of the algae appeared to be under the threshold for effective compensation of A. longimana.

The mechanism causing these patterns is unknown; however there are potential explanations. Gut traits impose a physical constraint on how much food can be processed per time. Below a certain threshold, an organism may not be able to ingest enough mass to acquire adequate levels of a particular nutrient (Sinclair 1975, Sinclair \& Norton-Griffiths 1979, Slansky 1993). For example, using diets that varied in protein and energy content, Bowen et al. (1995) showed that fish could compensate for energy requirements by increasing consumption, but not for protein because the fish could not consume enough food per time. Also, as feeding rates increase beyond a threshold, nutrient assimilation may decrease (Slansky \& Feeny 1977, Simpson \& Simpson 1990, Slansky 1993). If this occurs disproportionately for specific critical nutrients, then compensatory feeding will be of limited value. Finally, approximating food quality to broad categories such as soluble protein or total nitrogen may be misleading. For example, the digestibility of different proteins can 
vary qualitatively (Orskov 1982, Horie \& Watanabe 1983, Broadway \& Duffey 1988, Lovell 1989, Bureau et al. 1999).

Fitness of amphipods raised on algal mixtures was always matched by fitness on some monospecific diets, regardless of whether the algae offered alone were also present in the mixed treatments (Figs 4, 5, 6 \& 7). Although amphipods raised on algal mixtures tended to have higher average growth (Fig. 4b), amphipod survivorship and reproductive traits were similar among most treatments (Figs 4a \& 5) and growth on algal mixtures did not differ significantly from growth on at least 3 of the algae offered alone (Fig. 4b). Although Ampithoe longimana appears to consume a variety of foods in the field (Nelson 1979), this behavior could be related to food availability rather than a need to balance nutrient intake. Patterns similar to these have been found for other amphipods within the genus Ampithoe (Cruz-Rivera \& Hay 2000b) and for terrestrial insects (Bernays \& Minkenberg 1997).

Some marine consumers appear to benefit from dietary mixing (Lobel \& Ogden 1981, McTigue \& Zimmerman 1991, Pennings et al. 1993, Rodríguez et al. 1994, Cruz-Rivera \& Hay 2000b); however, access to mixed diets is not always beneficial over consuming single foods (Larson et al. 1980, Steinberg \& van Altena 1992, Rogers et al. 1995, Cruz-Rivera \& Hay 2000b). For small consumers such as mesograzers, mixing diets potentially involves moving among host algae. Predation risk can limit this behavior, especially if predators cue on movement. Mesograzers, however, may be able to reduce this risk by moving at night (Brawley 1992, Rogers et al. 1998). Some evidence suggests that this is the case for Ampithoe longimana (E. Sotka pers. comm.). If the amphipod leaves the alga it is on, this behavior can result in at least 2 scenarios: (1) amphipods may feed on algae of a different species than the one they were on and return to the former host after feeding bouts, or (2) amphipods may switch host algal species and stay on the new host. We therefore asked the question of how mixing diets affected fitness of $A$. longimana if the amphipods were to feed on alternating hosts of different quality for limited periods (24 h).

In this second long-term experiment, survivorship was very similar in all fed treatments (Fig. 6a), even when one of the diets was Codium, which tended to reduce survivorship in our first long-term experiment (Fig. 4a). However, growth was affected significantly by alternating diets (Figs 6b \& 7a), with the effect predominantly determined by the quality of the best food offered in each alternating pair of algae (Figs 6b \& 7a). Consistent with the results from our first long-term assay, having equal access to an algal mixture tended to enhance growth; however, this was matched by growth on Enteromorpha intestinalis alone (Figs 6b \& 7a). Also in accordance with our first assay, growth was lower on Sargassum and lowest on Codium. These 2 diets also decreased growth of the females and delayed ovulation (Fig. 7a,c), but patterns of female size at ovulation were less clear (Fig. 7b). Although differences were rarely significant, growth in all alternating dietary treatments tended to be lower than when amphipods had simultaneous access to all three algae. This suggests that access to the 3 algae may be better that than most combinations of 2 of them, or that alternating diets somehow constrains amphipod growth on these foods.

Although no other studies have measured the effects of this type of diet heterogeneity in marine consumers, Vadas (1977) noted that final growth of sea urchins was enhanced when they were switched from lower to higher quality algae after several months. Stockhoff (1993) found decreased growth when insects were switched sequentially between artificial diets of different nutrient content. To explain this result, he proposed that food quality was changing faster than the insects could compensate for nutritional differences. In the case of Ampithoe longimana, consuming alternating algae was equivalent to feeding on the higher quality alga, suggesting that these amphipods may obtain some benefit if they can graze on higher quality seaweeds at least for part of the time they spend eating. However, survivorship, fecundity, and egg size were not affected by treatment. In fact, when differences in growth on different diets were significant, fecundity or egg size for females ovulating were not affected in either of our 2 long-term assays. Because the conditions under which any effects were observed were so restrictive, the benefits of diet mixing for $A$. longimana appear to be limited.

A large scope for compensatory feeding, like we found for Ampithoe longimana, should reduce the need for diet mixing. This could benefit mesograzers indirectly by reducing the need of moving among host algae, thus reducing detection by predators. In $A$. longimana in fact, low mobility and association with chemically defended host algae enhance escape from predators (Duffy \& Hay 1994). A relation between low mobility and the ability to substitute food quantity for food quality via compensatory feeding may be more general than currently appreciated as it occurs in both crabs (Stachowicz \& Hay 1999) and amphipods (CruzRivera \& Hay 2000a). A. longimana shows strong preference for brown algae in the genus Dictyota (Hay et al. 1987, Duffy \& Hay 1991a, 1994) and noticeably damages this alga in the field (Cronin \& Hay 1996b); however, the nutritional value of this alga does not appear to explain this preference or the dietary consequences of diverse algae on fitness for this amphipod 
(Duffy \& Hay 1991a, Cronin \& Hay 1996a,b, this study). Algal chemical defenses and the associational escapes that they provide mesograzers from their own predators, rather than nutrient content, appear to have influenced the evolution of feeding preferences in A. longimana, and in many similar mesograzers for which food and shelter are tightly coupled (Hay et al. 1987, 1988a,b, Duffy \& Hay 1991b, 1994, Cruz-Rivera \& Hay 2000b, reviewed in Hay 1992, 1996, Hay \& Steinberg 1992).

The ability to use different feeding strategies may explain how Ampithoe longimana persists year-round at our field sites, and may be linked to its wide distribution (Bousfield 1973). Feeding selectivity during the summer allows this amphipod to escape predation by associating with, and consuming, the chemically defended alga Dictyota menstrualis (Hay et al. 1987, Duffy \& Hay 1991a, 1994). In the colder months, when predation by omnivorous fishes is at a minimum and Dictyota becomes locally extinct (Duffy \& Hay 1994), selectivity may be less important and compensation can allow the amphipod to persist on a wide diversity of algae that become abundant. Some discrimination based on nutritional quality may still offer a selective advantage if the amphipod avoids prolonged consumption of algae like Codium, which lie below the threshold for effective compensation. For low-mobility grazers that live in areas in which both algal foods and pressure from natural enemies vary with season, the use of alternative feeding strategies is likely to be important.

Acknowledgements. This research was conducted while both authors were at the Institute of Marine Sciences from the University of North Carolina at Chapel Hill, in Morehead City, NC. We are grateful to Sunny Floyd and Bernardo da Gama for technical assistance, to Howard Mendlovitz for running the CHN analyses, and to Erik Sotka for valuable comments on the manuscript. Support for this project was provided by NSF grant OCE 95-29784 to M.E.H.

\section{LITERATURE CITED}

Barnard JL, Karaman GS (1991) The families and genera of marine gammaridean Amphipoda (except marine gammaroids). Rec Aust Mus Suppl 13:1-866

Begon M, Harper JL, Townsend CR (1996) Ecology: individuals, populations and communities. Blackwell Scientific Publications, Boston

Bell SS (1991) Amphipods as insect equivalents? An alternative view. Ecology 72:350-354

Bernays EA, Graham M (1988) On the evolution of host specificity in phytophagous arthropods. Ecology 69:886-892

Bernays EA, Minkenberg OPJM (1997) Insect herbivores: different reasons for being a generalist. Ecology 78: $1157-1169$

Bolser RC, Hay ME, (1996) Are tropical plants better defended? Palatability and defenses of temperate vs. tropical seaweeds. Ecology 77:2269-2286
Bousfield EL (1973) Shallow water gammaridean Amphipoda of New England. Cornell University Press, Ithaca

Bowen SH, Lutz EV, Ahlgren MO (1995) Dietary protein and energy as determinants of food quality: trophic strategies compared. Ecology 76:899-907

Bradford MM (1976) A rapid and sensitive method for the quantification of microgram quantities of protein utilizing the principle of protein-dye binding. Analyt Biochem 72: 248-254

Brawley SH (1992) Mesoherbivores. In: John DM, Hawkins SJ, Price J (eds) Plant-animal interactions in the marine benthos. Clarendon Press, Oxford, p 235-263

Broadway RM, Duffey SS (1988) The effect of plant protein quality on insect digestive physiology and the toxicity of plant proteinase inhibitors. J Insect Physiol 34: 1111-1117

Bureau DP, Harris AM, Cho CY (1999) Apparent digestibility of rendered animal protein ingredients for rainbow trout (Oncorhynchus mykiss). Aquaculture 180:345-358

Chaudron Y, Poulet SA, Laabir M, Ianora A, Miralto A (1996) Is hatching success of copepod eggs diatom densitydependent? Mar Ecol Prog Ser 144:185-193

Conover WJ (1980) Practical nonparametric statistics, 2nd edn. Wiley, New York

Cronin G, Hay ME (1996a) Susceptibility to herbivores depends on recent history of both the plant and animal. Ecology 77:1531-1543

Cronin G, Hay ME (1996b) Induction of seaweed chemical defenses by amphipod grazing. Ecology 77:2287-2301

Crossman DJ, Clements KD, Cooper GJS (2000) Determination of protein for studies of marine herbivory: a comparison of methods. J Exp Mar Biol Ecol 244:45-65

Cruz-Rivera E, Hay ME (2000a) Can quantity replace quality? Food choice, compensatory feeding, and fitness of marine mesograzers. Ecology 81:201-219

Cruz-Rivera E, Hay ME (2000b) The effects of diet mixing on consumer fitness: macroalgae, epiphytes, and animal matter as food for marine amphipods. Oecologia 123:252-264

Davis EM (1988) Protein assays: a review of common techniques. Am Biotech Lab 6:28-37

DeLong MD, Summers RB, Thorp JH (1993) Influence of food type on the growth of a riverine amphipod, Gammarus fasciatus. Can J Fish Aquat Sci 50:1891-1896

Duffy JE, Hay ME (1991a) Food and shelter as determinants of food choice by an herbivorous marine amphipod. Ecology 72:1286-1298

Duffy JE, Hay ME (1991b) Amphipods are not all created equal: a reply to Bell. Ecology 72:354-358

Duffy JE, Hay ME (1994) Herbivore resistance to seaweed chemical defense: the roles of mobility and predation risk. Ecology 75:1304-1319

Duffy JE, Hay ME (2000) Strong impacts of grazing amphipods on the organization of a benthic community. Ecol Monogr 70:237-263

Fox LR, Morrow PA (1981) Specialization: species property or local phenomenon? Science 211:887-893

Graça MAS, Maltby L, Calow P (1993) Importance of fungi in the diet of Gammarus pulex and Asellus aquaticus. Oecologia 96:304-309

Gulati RD, DeMott WR (1997) The role of food quality for zooplankton: remarks on the state-of-the-art, perspectives and priorities. Freshw Biol 38:753-768

Hay ME (1992) The role of seaweed chemical defenses in the evolution of feeding specialization and in the mediation of complex interactions. In: Paul VJ (ed) Ecological roles of marine natural products. Comstock Publishing Assoc, Cornell University Press, Ithaca, p 93-118 
Hay ME (1996) Marine chemical ecology: what is known and what is next? J Exp Mar Biol Ecol 200:103-134

Hay ME (1997) The ecology and evolution of seaweed-herbivore interactions on coral reefs. Coral Reefs 16:67-76

Hay ME, Fenical W (1988) Marine plant-herbivore interactions: the ecology of chemical defense. Annu Rev Ecol Syst 19:111-145

Hay ME, Steinberg PD (1992) The chemical ecology of plantherbivore interactions in marine versus terrestrial communities. In: Rosenthal GA, Berenbaum MR (eds) Herbivores: their interactions with secondary plant metabolites, Vol. II, ecological and evolutionary processes. Academic Press, San Diego, p 372-408

Hay ME, Duffy JE, Pfister CA, Fenical W (1987) Chemical defense against different marine herbivores: are amphipods insect equivalents? Ecology 68:1567-1580

Hay ME, Renaud PE, Fenical W (1988a) Large mobile versus small sedentary herbivores and their resistance to seaweed chemical defenses. Oecologia 75:246-252

Hay ME, Duffy JE, Fenical W, Gustafson K (1988b) Chemical defense in the seaweed Dictyopteris delicatula: differential effects against reef fishes and amphipods. Mar Ecol Prog Ser 48:185-192

Hay ME, Kappel QE, Fenical W (1994) Synergisms in plant defenses against herbivores: interactions of chemistry, calcification, and plant quality. Ecology 75:1714-1726

Hay ME, Piel J, Boland W, Schnitzler I (1998a) Seaweed sex pheromones and their degradation products frequently suppress amphipod feeding but rarely suppress sea urchin feeding. Chemoecology 8:91-98

Hay ME, Stachowicz JJ, Cruz-Rivera E, Bullard S, Deal MS, Lindquist $N$ (1998b) Bioassays with marine and freshwater macroorganisms. In: Haynes KF, Millar JG (eds) Methods in chemical ecology, Vol 2, bioassay methods. Chapman and Hall, New York, p 39-141

Horie Y, Watanabe K (1983) Effect of various kinds of dietary protein and supplementation with limiting amino acids on growth, haemolymph components and uric acid excretion in the silkworm Bombyx mori. J Insect Physiol 29:187-199

Kaehler S, Kennish R (1996) Summer and winter comparisons in the nutritional value of marine macroalgae from Hong Kong. Bot Mar 39:11-17

Kennish R (1997) Seasonal patterns of food availability: influences on the reproductive output and body condition of the herbivorous crab Grapsus albolineatus. Oecologia 109:209-218

Kennish R, Williams GA (1997) Feeding preferences of the herbivorous crab Grapsus albolineatus: the differential influence of algal nutrient content and morphology. Mar Ecol Prog Ser 147:87-95

Kneib RT, Newell SY, Hermeno ET (1997) Survival, growth and reproduction of the salt-marsh amphipod Uhlorchestia spartinophila reared on natural diets of senescent and dead Spartina alterniflora leaves. Mar Biol 128:423-431

Larson BR, Vadas RL, Keser M (1980) Feeding and nutritional ecology of the sea urchin Strongylocentrotus drobachiensis in Maine, USA. Mar Biol 59:49-62

Lindquist N, Hay ME (1995) Can small rare prey be chemically defended? The case for marine larvae. Ecology 76 : $1347-1358$

Lobel PS, Ogden JC (1981) Foraging by the herbivorous parrotfish Sparisoma radians. Mar Biol 64:173-183

Lovell T (1989) Nutrition and feeding of fish. AVI Books, Van Nostrand Reinhold, New York

Mattson WJ Jr (1980) Herbivory in relation to plant nitrogen content. Annu Rev Ecol Syst 11:119-161

McTigue TA, Zimmerman RJ (1991) Carnivory vs herbivory in juvenile Penaeus setiferus (Linnaeus) and Penaeus aztecus (Ives). J Exp Mar Biol Ecol 151:1-16

Miralto A, Barone G, Romano G, Poulet SA, Ianora A, Russo GL, Buttino I, Mazzarella G, Laabir M, Cabrini M, Glacobbe MG (1999) The insidious effect of diatoms on copepod reproduction. Nature 402:173-176

Morán JAG, Arrontes J (1994) Factors affecting food preference in a widespread intertidal isopod. J Exp Mar Biol Ecol 182:111-121

Neighbors MA, Horn MH (1991) Nutritional quality of macrophytes eaten and not eaten by two temperate-zone herbivorous fishes: a multivariate comparison. Mar Biol 108: 471-476

Nelson WG (1979) An analysis of structural pattern in an eelgrass (Zostera marina L.) amphipod community. J Exp Mar Biol Ecol 39:231-264

Orskov ER (1982) Protein nutrition in ruminants. Academic Press, London

Paul VJ (1992) Ecological roles of marine natural products. Cornell University Press, Ithaca

Pennings SC, Paul VJ (1992) Effect of plant toughness, calcification, and chemistry on herbivory by Dolabella auricularia. Ecology 73:1606-1619

Pennings SC, Masatomo TN, Paul VJ (1993) Selectivity and growth of the generalist herbivore Dolabella auricularia feeding upon complementary resources. Ecology 74: $879-890$

Pennings SC, Carefoot TH, Siska EL, Chase ME, Page TA (1998) Feeding preferences of a generalist salt-marsh crab: relative importance of multiple plant traits. Ecology 79:1968-1979

Peterson CH, Renaud PE (1989) Analysis of feeding preference experiments. Oecologia 80:82-86

Poore AGB, Steinberg PD (1999) Preference-performance relationships and effects of host plant choice in a herbivorous marine amphipod. Ecol Monogr 69:443-464

Poulet SA, Laabir M, Ianora A, Miralto A (1995) Reproductive response of Calanus helgolandicus. I. Abnormal embryonic and naupliar development. Mar Ecol Prog Ser 129: $85-95$

Price PW, Bouton CE, Gross P, McPheron BA, Thompson JN, Weiss AE (1980) Interactions among three trophic levels: influence of plants on interactions between insect herbivores and natural enemies. Annu Rev Ecol Syst 11:41-65

Pyke GH (1984) Optimal foraging theory: a critical review. Annu Rev Ecol Syst 15:523-575

Robertson AI, Lucas JS (1983) Food choice, feeding rates, and the turnover of macrophyte biomass by a surf-zone inhabiting amphipod. J Exp Mar Biol Ecol 72:99-124

Rodríguez A, Le Vay L, Mourente G, Jones DA (1994) Biochemical composition and digestive enzyme activity in larvae and postlarvae of Penaeus japonicus during herbivorous and carnivorous feeding. Mar Biol 118:45-51

Rogers CN, Steinberg PD, de Nys R (1995) Factors associated with oligophagy in two species of sea hares (Mollusca: Anaspidea). J Exp Mar Biol Ecol 192:47-73

Rogers CN, Williamson JE, Carson DG, Steinberg PD (1998) Diel vertical movement by mesograzers on seaweeds. Mar Ecol Prog Ser 166:301-306

Rueda AA, Slansky F Jr, Wheeler GS (1991) Compensatory response of the slug Sarasinula plebeia to dietary dilution. Oecologia 88:181-188

Schneider CW, Searles RB (1991) Seaweeds of the southeastern United States: Cape Hatteras to Cape Canaveral. Duke University Press, Durham

Schnitzler I, Boland W, Hay ME (1998) Organic sulfur compounds from Dictyopteris spp. (Phaeophyceae) deter feed- 
ing by an herbivorous amphipod (Ampithoe logimana) but not by an herbivorous sea urchin (Arbacia punctulata). J Chem Ecol 24:1715-1732

Simpson SJ, Simpson CL (1990) The mechanisms of nutritional compensation by phytophagous insects. In: Bernays EA (ed) Insect-plant interactions, Vol. 2. CRC Press, Boca Raton, p 111-160

Sinclair ARE (1975) The resource limitation of trophic levels in tropical grassland ecosystems. J Animal Ecol 44: 497-520

Sinclair ARE, Norton-Griffiths M (1979) Serengeti: dynamics of an ecosystem. University of Chicago Press, Chicago

Slansky F Jr (1993) Nutritional ecology: the fundamental quest for nutrients. In: Stamp NE, Casey TM (eds) Caterpillars: ecological and evolutionary constraints on foraging. Chapman and Hall, New York, p 29-91

Slansky F Jr, Feeny P (1977) Stabilization of the rate of nitrogen accumulation by larvae of the cabbage butterfly on wild and cultivated food plants. Ecol Monogr 47:209-228

Sokal RR, Rohlf FJ (1981) Biometry. WH Freeman and Company, New York

Southwood TRE (1973) The insect/plant relationship - an evolutionary perspective. Symp Roy Entomol Soc London $6: 3-30$

Stachowicz JJ, Hay ME (1996) Facultative mutualism between an herbivorous crab and a coralline alga: advantages of eating noxious seaweeds. Oecologia 105:377-387

Stachowicz JJ, Hay ME (1999) Reduced mobility is associated

Editorial responsibility: Charles Birkeland (Contributing Editor), Honolulu, Hawaii, USA with compensatory feeding and increased diet breadth of marine crabs. Mar Ecol Prog Ser 188:169-178

Steinberg PD, van Altena I (1992) Tolerance of marine invertebrate herbivores to brown algal phlorotannins in temperate Australasia. Ecol Monogr 62:189-222

Stephens DW, Krebs JR (1986) Foraging theory. Princeton University Press, Princeton

Sterner RW, Hessen DO (1994) Algal nutrient limitation and the nutrition of aquatic herbivores. Annu Rev Ecol Syst 25:1-29

Stockhoff BA (1993) Diet heterogeneity: implications for growth of a generalist herbivore, the gypsy moth. Ecology 74:1939-1949

Stoyenoff JL, Witter JA, Montgomery ME, Chilcote CA (1994) Effects of host switching on gypsy moth (Lymantria dispar (L.)) under field conditions. Oecologia 97:143-157

Strong DR, Lawton JH, Southwood R (1984) Insects on plants. Harvard University Press, Cambridge

Vadas RL (1977) Preferential feeding: an optimization strategy in sea urchins. Ecol Monogr 47:337-371

Wakefield RL, Murray SN (1998) Factors influencing food choice by the seaweed-eating marine snail Norrisia norrisi (Trochidae). Mar Biol 130:631-642

Werner EE, Hall DJ (1974) Optimal foraging and the size selection of prey by the bluegill sunfish Lepomis macrochirus. Ecology 55:1042-1052

White TCR (1993) The inadequate environment: nitrogen and the abundance of animals. Springer-Verlag, New York

Submitted: August 24, 2000; Accepted: January 24, 2001 Proofs received from author(s): July 18, 2001 